\title{
Regulation of annual weight cycles in reindeer and other cervids
}

\author{
MORTEN RYG
}

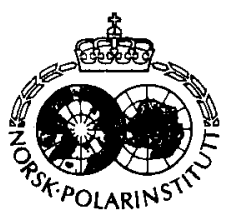

Ryg, M. 1983: Regulation of annual weight cycles in reindeer and other cervids. Polar Research 1 n.s., 249-257.

Seasonal changes in weight, food intake and metabolic rate are characteristic of reindeer and other northern ungulates. This article reviews relationships between endocrine and weight cycles in reindeer and other cervids, and the effect of manipulations with endocrine cycles upon the weight cycle. It appears that the secretions of most endocrine glands change throughout the year, either as a result of nutritional changes or of an inherent seasonal rhythm. It is suggested that the weight and metabolic cycles are secondary to an appetite cycle that is hormonally regulated. The hormonal control may include several hormones: sex steroids, thyroid hormones, and prolactin.

Morten Ryg, Zoofysiologisk institutt, Postboks 1051 Blindern, Osio 3, Norway.

\section{Introduction}

It is well known to reindeer herders that the reindeer grow slowly or lose weight in the winter, and gain weight rapidly during summer (Skjenneberg 1965). This cyclic pattern is not dependent on the seasonal changes in food quality and availability as it occurs also when a standard feed is offered ad libitum throughout the year. The annual weight cycle and accompanying cycles of food intake and metabolic rate seem to be genetic features shared by a number of northern ungulates including cervids, sheep, muskox, chamois, and one antelope, the saiga (French et al. 1956; McEwan 1968; Wandeler \& Huber 1969; McEwan \& Whitehead 1970; Bandy et al. 1970; McEwan 1975; Knorre 1961; Abaturov et al. 1982). These cycles are probably adaptations, partly to seasonal fluctuations in food quality and quantity, and partly to the strains of reproduction.

The physiological regulation of the weight cycle is not well known. In this paper, the possible significance of endocrine factors is discussed. Because our knowledge of the reindeer is often scant or lacking, I shall also draw on results obtained using other cervid species.

\section{Characteristics of the annual cycle}

\section{Dependence on age and sex}

With adequate nutrition, fawns of all cervid species grow uninterrupted from birth, usually in
May or June, to October-November when weight gain declines. Weight changes during the winter are dependent on nutrition (see p. 250) and on the weight of the fawn at the beginning of the winter. With adequate nutrition a small fawn can gain more weight than a large one. Blaxter et al. (1981) observed that the weight gain of red deer fawns from 3 to 9 months of age was inversely proportional to body weight at weaning. Although the data were not presented, the same appears to be true for white-tailed deer (Moen 1973:165) and moose (Knorre 1961). The weight gain increases in both yearlings and older animals in April or May. In some races of the widely distributed Odocoileus hemionus (mule deer and black-tailed deer), a slight weight gain in April or May is often followed by a period of relative constant weight in June and July, and most of the weight gain in the summer occurs after midsummer (Bandy et al. 1970). Blaxter et al. (1974) noted a regular transient decline in the weight gain of the red deer in June and July. A similar halt, or weight loss, in June and July was also reported by Ryg \& Jacobsen (1982a) in reindeer. Because of the regular occurrence of the phenomenon, Blaxter et al. (1974) doubted that it was due to excessive heat or insect harassment. A transient halt in the weight gain in midsummer may be a regular occurrence in cervids. It may be physiologically regulated, as it appears from the data of Ryg \& Jacobsen (1982a) that weight changes in midsummer were related to body weight; the larger the initial body weight, the 
greater the weight loss (expressed as \% of body weight as well as in absolute terms). Another halt, or weight loss, occurs during the rutting season. The weight loss of rutting males usually increases with increasing age (French et al. 1956; Knorre 1961; McEwan 1968; Nordan et al. 1968; Bandy et al. 1970; Ryg \& Langvatn 1982). As also noted by Nordan et al. (1968) this could be due to the larger body weight of older animals, since the weight loss of $1 \frac{1}{2}$-year-old reindeer males was related to body weight (Ryg \& Jacobsen 1982a). Throughout the rest of the winter, the body weight declines most in the older (and heavier) males. It thus appears that weight changes throughout the autumn and winter (beginning with rut in the adults), and possibly also during a short period in the summer are related to the weight of the animal.

Food consumption in animals fed ad libitum follows a pattern consistent with the changes in body weight. Food intake is higher in the summer than in the winter, and is especially low during the rutting season. In late summer and autumn. prior to the rut, food intake often reaches peak values, especially in older males. Metabolic rates are as much as $40 \%$ lower in the winter than in the summer in white-tailed deer (Silver et al. 1969) and reindeer (Segal 1962; McEwan \& Whitehead 1970). In roe deer the differences were smaller (Weiner 1977), and no seasonal differences were found in one red deer hind fed a maintenance ration throughout the year (Brockway \& Maloiy 1967).

Skeletal development has been less studied than changes in body weight. Knorre (1961) found that shoulder height and shoulder-to-ischium length did not change appreciably between 6 and 12 months of age in moose calves kept in enclosures with natural vegetation. From studies of caribous shot at different times throughout the year. Dauphiné (1976) found low rates of increase in mandible, metatarsus and total body length, and in shoulder height from December to May. On the other hand, in reindeer calves fed ad libitum, Ryg \& Jacobsen (1982a) found that total length and the length of the lower jaw did not increase from October to January, while both total and jaw lengths increased steadily from January onwards. There was even a tendency to slower growth in the summer than in the winter. A similar pattern was noted in red deer fawns shot at different seasons by Mitchell et al. (1976), and in roe deer and chamois fawns by Wandeler
\& Huber (1969). Mean jaw lengths and basilar lengths did not change from October to November, but from February and the rest of the winter jaw lengths increased. Basilar length was practically constant in yearling roe deer and chamois from 12 months of age, i.e. from June-July in their second summer of life.

\section{Effects of nutrition}

The appearance of the growth cycle is dependent on the quality and quantity of available food. Nordan et al. (1968) found no seasonal pattern in one white-tailed buck fed $60 \%$ of ad libitum intake throughout the year for two years. There was no evident weight loss during the rut, and weight gain continued uninterrupted throughout the winters. The lack of weight loss during rut could be due to the slow weight gain of this animal in the summer, since weight loss during rut may be size-related (see p. 249). The animal with a reduced ration did not reach the same weight as the $1 \frac{1}{2}$-year-old bucks having free access to food, and thus may not have reached a weight where a loss during the rut normally occurs.

Food intake and weight changes in animals fed ad libitum depends on the quality of the food. It seems that, in wild and domestic ruminants alike, the intake of natural foods is limited by the capacity of the gastrointestinal system and the passage rate of the food. In animals with similar physiological status, the voluntary intake of roughage is inversely related to gastrointestinal turnover (Hjeljord et al. 1982; Milne et al. 1978). The turnover rate, in turn, is related to the maturity and degree of lignification of the plants. So, the appetite and weight cycles seen in animals on standard diets will be accentuated by the seasonal changes in food quality. Also, hypertrophy of the rumen, which occurs in the summer (Staaland et al. 1974; Mitchell et al. 1976) would allow a greater intake for a certain turnover rate. In red deer, intake of various roughages was greater in the spring than in midwinter, although gastrointestinal turnover did not change systematically (Milne et al. 1978). Some metabolic control of food intake probably also occurs. During the winter, intake of lichen is higher in free-ranging than in penned reindeer (Holleman et al. 1979), and lactating red deer (Clutton-Brock et al. 1982) and reindeer (White 1979) spend more time grazing than non-lactating females.

Differences in patterns of skeletal development 
(see p. 250) could be due to nutrition. Ryg \& Jacobsen (1982a) reported that the total length increased slower during the winter in reindeer calves with restricted ration than in calves fed ad libitum. On the other hand, skeletal growth from October to January was equally retarded in reindeer calves fed ad libitum and with restricted ration, and has been observed in free-ranging as well as captive animals of other species (see p. 250). This growth retardation could be caused by other than nutritional factors.

\section{Effects of photoperiod}

Cycles of food intake, weight gain, antler growth and reproductive changes in red deer are entrained by photoperiod (Pollock 1975). However, the cycles need not be entirely determined by photoperiod. Goss (1969a, b; 1976) concluded, from studies on antler development in Sika deer, that an endogenous circannual rhythm exists that can be entrained by either increasing or decreasing day lengths. With certain artificial lighting regimes, antler development lost its relation to photoperiod and returned to a more or less 360 days cycle.

Changing day lengths could affect food intake by an influence on the daily activity pattern. Eriksson et al. (1981) reported that feeding activity of reindeer fed ad libitum throughout the year was determined by an interaction between photoperiod and an ultradian activity rhythm. Food consumption varied in accordance with the seasonal changes in the activity pattern. Thus it is possible that seasonal changes in food consumption to some degree is brought about by behavioral changes that are not related to energy requirements or gastrointestinal function. Knorre (1961) reported that moose calves gained less weight in excessively warm summers. Under such conditions, they were relatively inactive during the day, and did not increase their nightly food intake sufficiently to compensate for the reduced foraging time during the day. However, the annual food intake cycle cannot be explained completely by this effect. Some investigations have shown that the food intake is maintained or even increased during the shortening days in the late summer (Nordan et al. 1968; McEwan 1975; Ryg \& Jacobsen 1982a, b). Even if total feeding time were restrained within an ultradian rhythm, the amount of food taken during each eating period can change, and this may cause deviations from a direct correlation between total eating time and total food consumption (Arnold 1981). There is also evidence that total grazing time can change in response to increased energy demand or decreased instantaneous intake (see p. 250; White 1979).

\section{Endocrine correlates of the annual cycle}

\section{The gonads}

A relationship between the weight cycle and gonadal activity has been noted in many investigations. The pronounced weight loss in the autumn coincides with rutting behaviour and increasing testosterone levels (McEwan 1975; Ryg \& Jacobsen 1982b). Cessation of weight gain in red deer in the autumn was age-dependent; older animals coming into rut earlier also stopped gaining weight earlier than younger animals (Ryg \& Langvatn 1982). The weight loss during rut is also greatest in older animals, although this may be an effect of size rather than age (see p. 250). Sex differences are also evident, the weight fluctuations are less pronounced in females than in males (Nordan et al. 1968). In addition, the course of depletion of fat stores is sex specific. Dauphiné (1976) found that most of the subcutaneous, perirena! and abdominal fat disappeared during the rut in adult male caribou, whereas pregnant females lost most fat during the last half of pregnancy. Similar patterns were observed in red deer (Mitchell et al. 1976). The relationship between the weight, food intake and reproductive cycles persists when the photoperiod is manipulated (Pollock 1975). All these observations suggest an effect of gonadal factors on the weight pattern, or that the neuroendocrine mechanisms regulating the reproductive cycle also influence the growth and fattening cycles.

\section{The thyroid gland}

It has been suggested repeatedly that the thyroid gland is involved in the regulation of seasonal changes in the metabolic rate (Silver et al. 1969; Seal et al. 1972; Ringberg et al. 1978). Hoffman \& Robinson (1966) found that the follicular epithelium of the thyroid of white-tailed deer was higher in the summer than in the winter; similar results were obtained in roe deer (Pantić \& Stošić 1966) and red deer (Pantić \& Stošić 1966; Eickhoff 
1957). In contrast, Graflin (1942) found no seasonal variations in the histological picture of white-tailed deer shot at intervals throughout the year. Biochemically, the rate of thyroxine (T4) secretion has been measured by estimating $\mathrm{T} 4$ concentrations in plasma, and disappearance rates of radioactively labelled $\mathrm{T} 4$. By this method, Yousef \& Luick (1971) found no significant differences in $\mathrm{T} 4$ turnover in caribou between the months January, April, and August. This does not contradict the hisotological observations, since from the histological pictures, the greatest changes in activity occur in May and June.

Compatible with most of the histological findings, seasonal variations in plasma $\mathrm{T} 4$ levels, with highest levels in the early summer, have been reported in captive and free-ranging Norwegian reindeer (Ringberg et al. 1978; Ryg \& Jacobsen 1982a), in free-ranging Svalbard reindeer (Ringberg 1979) and in captive moose (Ryg 1982). Similar seasonal variations were found in whitetailed deer by Oelschlaeger et al. (1980), but not by Bubenik \& Bubenik (1978), although in the latter investigation, there tended to be a transient increase in $\mathrm{T} 4$ levels in the spring or early summer. In male red deer. Ryg \& Langvatn (1982) found no consistent seasonal differences in T4 levels. In male and female roe deer, and in one adult male Svalbard reindeer, levels were highest in December. but there were transient increases in June or July, and a nadir in September (Barth \& Horn 1980; Nilssen \& Ringberg 1980). Also in yearling mainland reindeer, $\mathrm{T} 4$ levels tended to rise in the late autumn, after a transient decrease in September (Ryg \& Jacobsen 1982a). Thus, although there are considerable variations in the reported seasonal patterns there tend to be two peaks in T4 levels - one in the early summer and one in the early winter. Some differences could be attributed to the effects of different nutrition. Restricted food intake over long periods depressed T4 levels in reindeer (Ryg \& Jacobsen 1982a) and white-tailed deer (Seal et al. 1972). T4 levels were lower in March than in August in free-ranging Svalbard reindeer, but not in a captive animal fed ad libitum (Nilssen \& Ringberg 1980). On the other hand, Ryg \& Jacobsen (1982a) found that T4 levels in yearling reindeer increased in the spring in animals with a restricted diet, and concluded that changes in T4 levels are at least partly seasonally determined.

T4 is much less active than its metabolite triiodothyronine (T3), and possibly $\mathrm{T} 4$ is primarily a prohormone for T3 (Bernal et al. 1981). Seasonal variations in $\mathrm{T} 3$ concentrations in plasma, with highest levels in the summer, have been reported in male reindeer (Ryg \& Jacobsen 1982a), red deer (Ryg \& Langvatn 1982), moose (Ryg 1982), and white-tailed deer (Oelschlaeger et al. 1980). In white-tailed does, highest $\mathrm{T} 3$ levels were found in May, but thereafter the levels declined, reaching minimal values in August (Bahnak et al. 1981). Ryg \& Jacobsen (1981, 1982a) found that the seasonal changes in T3 levels could to a large extent be explained by changing food intake. No increase occurred in the spring when food was restricted, and changes in $T 3$ levels could be induced by alterations in food intake. Some support for this idea was also given by studies on moose (Ryg 1982). In contrast, Westra \& Hudson (1981) found that T3 levels in wapiti calves decreased in the spring, although food intake increased. Nilssen (pers. comm.) found that short-time fasting depressed T3 levels in Svalbard reindeer, but not in mainland Norwegian reindeer. I have no explanation for these differences. In addition to the amount of food eaten, food quality can influence the T3 levels. Seal et al. (1978) found that T3 levels in white-tailed deer were lowest in animals given a diet with low energy content. Finally, it cannot be excluded that in some species, seasonally determined changes in the thyroid secretion rate and T4 levels contribute to the changes in T3 levels, and so anticipate changes in $\mathrm{T} 3$ production caused by food quality and quantity. The lowering of the metabolic rate of reindeer in the winter is possibly secondary to the lowering of food intake (Nilssen et al. 1982; Nilssen pers. comm.). Ryg (1983) suggested that the metabolic changes could be mediated by the effect of nutrition on T3 levels. However, Nilssen et al. (1982) and Nilssen (pers. comm.) found that T3 levels were generally poorly correlated with metabolic rates, and so T3 cannot be the only regulator involved.

\section{Endocrine pancreas and insulin-like activity}

Seal et al (1978) reported that the composition of the feed affected insulin levels in white-tailed deer; high energy content of the diet caused increased insulin levels as compared with a medium-energy diet. Surprisingly, glucagon was unaffected by either protein or energy content of the diet; possibly effects of handling obscured any nutritional effects. To my knowledge, there are 
no reports of seasonal changes of insulin or glucagon levels in cervids.

Ringberg et al. (1978) found that somatomedin levels of free-ranging reindeer were higher in February than in July and August. This was interpreted in the light of the insulin-like effects of somatomedin. High levels in winter could prevent excessive lipolysis, and might be a mechanism for economizing with energy resources. However, this interpretation is complicated by the effect of energy intake on insulin levels (Seal et al. 1978). Reduced energy intake during winter will possibly depress insulin levels, and it is difficult to predict how the total insulin-like activity in plasma will change during the year. Sornatomedin stimulates specifically the growth of cartilage and participates in the regulation of skeletal growth (Raisz \& Kream 1981). Ryg \& Jacobsen (1982a) observed that mandible length in yearling reindeer started to increase in January, and that the rate of increase tended to decline during summer. This corresponds fairly well with the higher somatomedin levels in February as compared with July and August.

\section{The hypophysis}

Seasonal changes in parameters related to hypophysial activity have been reported in a number of cervid species. Hoffman \& Robinson (1966) reported that the weight of the hypophysis relative to body weight in male white-tailed deer was minimal in January and February, and maximal in May and June. This agrees with what Stošić and Pantić (1966) and Lincoln (1971) found in red deer stags. Stošić and Pantić also found histological changes in the hypophysis; acidophilic (secreting growth hormone and prolactin) and basophilic (secreting thyrotropin and gonadotrophins) cells were smaller in the winter than in the summer and contained less granules, indicating less secretory activity. In male mule deer, cytoplasmic and nuclear areas of acidophils were minimal in the winter (Nicolls 1971). In contrast to other studies, large nuclear areas were also found in the autumn (21 September to 20 December). Schulte et al. (1980, 1981b), using immunocytochemical staining to identify prolactin and growth hormone producing cells in white-tailed deer, found that the cellular volume density of prolactotrophs increased in the summer, probably caused by hypertrophy of the cells. There were no seasonal changes in the cytology of somato- trophs, but a transient $50 \%$ reduction of volume density took place in April and May.

Consistent with the histological observations, seasonal changes in serum prolactin concentrations, with highest levels in the summer, have been reported in male white-tailed deer (Mirarchi et al. 1978; Schulte et al. 1981a) and red deer (Suttie 1980). Thus, secretion of prolactin follows roughly the same seasonal pattern as weight and food intake. Like the growth cycle, prolactin secretion is controlled by changes in day length (Brown et al. 1979), and the increase of prolactin levels in the spring in red deer is not dependent on increased food intake, as it occurs also in animals fed a restricted diet (Suttie 1980). These observations suggest that prolactin may be involved in the control of food intake and growth in cervids. This has also been suggested for other ruminants; Forbes et al. (1979) found increased weight gain and prolactin levels in sheep, in response to longer days, whereas growth hormone, insulin and thyroxine concentrations were unaffected by day length as such.

The apparent involution of somatotrophs in the late winter is in strong contrast to measurements of growth hormone in serum. Elevated levels of growth hormone in April or May have been reported in white-tailed deer (Bubenik et al. 1975), moose (Ryg 1982), red deer (Ryg \& Langvatn 1982), Norwegian reindeer (Ryg \& Jacobsen 1982a), and Svalbard reindeer (Ringberg 1979), that is, high growth hormone levels are found in a period when the histological picture indicates low activity. There seems to be little correlation between growth hormone levels and increased weight gain, since growth hormone levels are mostly low during the summer.

\section{Effects of manipulation with endocrine cycles}

\section{The hypophyseo-gonadal axis}

Since the reproductive and growth cycles are closely related, under both natural and controlled photoperiods, it would be reasonable to suggest a causal relationship. West \& Nordan (1976) found that methallibure, a non-steroidal drug suppressing gonadotrophin secretion, inhibited food intake and weight gain of male black-tailed deer. However, as also observed by the authors, the effect may have been directly on the central mech- 
anisms controlling food intake, and not via gonadotrophins and gonadal factors.

Castration abolished the seasonal cycles of food intake and weight in one adult male black-tailed deer (McEwan 1975). In contrast, cyclic patterns were evident in castrated male reindeer (Ryg \& Jacobsen 1972b), red deer (Brown et al. 1979), and moose (Knorre 1961; Ryg 1982). In reindeer, the patterns were modified; the food intake of the castrates was lower than in the intact animals in late summer, and the pronounced weight loss seen in the intact animals from late September to the middle of October did not occur in the castrates. From these data, Ryg \& Jacobsen (1982b) suggested that at least two components may be involved in the control of cyclic weight and food intake in male cervids, one related to testicular activity, and one non-gonadal. The contributions of these components may vary between species and age groups.

\section{Prolactin and thyroid hormones}

Ryg \& Jacobsen (1982c) found that treatment of yearling male reindeer with either thyroid hormones or prolactin resulted in increased food intake. The effects on body weight were opposite; prolactin caused increased weight gain relative to controls, whereas thyroid hormones caused decreased gain, or weight loss. The results were taken as evidence that prolactin could be an endocrine link between changing day lengths and cyclic weight gain. This agrees with the suggestion of Suttie (1980). that increased food intake of red deer in the spring was caused by increasing prolactin levels. However, Suttie found a lag of about ten weeks between increasing prolactin and increasing food intake, whereas Ryg \& Jacobsen found that the effect of prolactin treatment was evident two days after the start of the treatment.

\section{The pineal gland}

The pineal gland is probably involved in the ability to respond to photoperiod. In the seasonally breeding Soay ram, the testicles can be brought to repetitively develop and regress in response to alternating 16-week periods of short days $(8 \mathrm{~h}$ light: $16 \mathrm{~h}$ dark) and long days (16 h light: $8 \mathrm{~h}$ dark). When the superior cervical ganglion was removed, thereby removing all nervous input to the pineal, the animals lost the ability to respond to changes in photoperiod (Lincoln \& Short 1980).

Recently, Bubenik (1983) reported that melatonin administration to white-tailed bucks in the early summer advanced the antler, molting and reproductive cycles by several months. On the other hand, Brown et al. (1978) found that pinealectomy of white-tailed deer did not overtly affect weight, food intake or reproductive cycles during the first year after pinealectomy. However, pinealectomy of one juvenile buck delayed the antler and molting cycles, indicating that the pineal is important for the establishment of the first cycle. Snyder et al. (1983) recently reported that pinealectomy of white-tailed bucks delayed antler growth and rubout, and delayed the seasonal cycles of prolactin and testosterone, but did not abolish any of these cycles. The authors suggested that the pineal gland synchronizes a circannual rhythm that is generated in another part of the brain. This is similar to what Goss (1969a, b, 1976) suggested for the effect of light on the annual cycle of the Sika deer (see p. 251).

\section{Endocrine regulation of the annual cycle - summary}

Regulation of food intake involves processing of sensory, gastrointestinal, and metabolic stimuli by the central nervous system. Hormonal control could be effectuated on the signals, by affecting gastrointestinal capacity, macromolecule synthesis, or basal metabolic rate; or on the central processing. for example by altering the central sensitivity to signals. If central sensitivity became extremely low, physiological control would be functionally decoupled and could be replaced by behavioral control, i.e. the amount of food eaten would be determined by the rhythm of feeding activity and would be unrelated to energy requirements. Eriksson et al. (1981) presented evidence for a behavioral control of food intake in reindeer. On the other hand, gastrointestinal and metabolic control of intake is suggested by a number of investigations (see pp. 249-250). Possibly the contributions from the different modes of control change during the year. If metabolic control is less strict in the summer, overeating could result in rapid growth in young animals, and fattening in the adults. So, cyclic growth and fattening could both be secondary to an appetite cycle.

Endocrine rhythms possibly related to the 
annual cycle include (1) increased gonadotrophin secretion and gonadal activity towards the end of the growth season; (2) increased plasma levels of growth hormone coinciding with the onset of antler growth, skeletal growth under conditions of restricted food supply, and onset of rapid weight gain; (3) increased plasma levels of prolactin, triiodothyronine and, in some species, thyroxine, coinciding with the period of increased food intake and rapid weight gain. Triiodothyronine is primarily controlled by nutrition, whereas the other endocrine rhythms are, at least partly, seasonally determined. In red deer kept with artificially changing photoperiod with natural amplitude but six-month period, changes in food intake and weight could not be explained by changes in the plasma levels of any single hormone (Brown et al. 1979). This agrees with the suggestion that hormonal control includes at least two components, one related to gonadal activity, and one non-gonadal. The non-gonadal component could be a complex of hormones including prolactin and, at least in some species, thyroxine. Seasonal changes in metabolic rate may be secondary to changes in food consumption, the control being partly mediated through changing triiodothyronine levels. It remains unknown if thyroxine has functions that are not reflected in the levels of circulating triiodothyronine.

The mechanisms controlling the annual endocrine cycles may involve both an endogenous, circannual rhythm, and the interaction of photoperiod with an endogenous, circadian clock (see p. 251). There may be common elements in the neuroendocrine regulation of the reproductive cycle, the antler cycle, and the cycles of food intake and weight.

\section{References}

Abaturov, B. D., Holodova, M. V. \& Subbotin. A. E. 1981: Intensivnost potreblenija i perevarimost kormov u Sajgakov (Saiga tatarica). (Intensity of consumption and digestibility of food in Saiga tatarica.) Zool. Zh. 61, 1870-1881.

Arnold, G. W. 1981: Grazing behaviour. Pp. 79-104 in Moriey, F. H. W. (ed.): World Animal Science B1: Grazing Animals. Elsevier Sci. Publishing Co. Amsterdam, Oxford, New York.

Bahnak, B. R., Holland, J. C., Verme, L. J. \& Ozoga, J. J. 1981: Seasonal and nutritional influences on growth hormone and thyroid activity in white-tailed deer (Odocoileus virginianus). J. Wildl. Manage. 45, 104-147.

Bandy. P. J., McTaggart Cowan. I. \& Wood, A. J. 1970: Comparative growth in four races of black-tailed deer (Odocoileus hemionus). Part I. Growth in body weight. Can. J. Zool. 48, 1401-1410.
Barth, D. \& Horn, K. 1980: Untersuchungen über das jahreszyklische Verhalten der Blutspiegel von Thyroxin und Harnstoff beim Reh (Capreolus capreolus). Z. Jagdwiss. 26, $1-11$.

Bernal, J., Obregon, M. J., Rodriguez-Peña, A., Mallol, J., Hernandez, P., Escobar del Rey, F. \& Morreale de Escobar, G. 1981: Metabolism and action of thyroid hormones. Pp. 107-121 in Dumont, J. E. \& Nunez, J. (eds.): Hormones and Cell Regulation, Vol. 5. Elsevier/North Holland Biomedical Press.

Blaxter, K. L., Boyne, A. W. \& Hamilton, W. J. 1981: Reproduction in farmed red deer. 3. Hind growth and mortality. J. Agric. Sci. Camb. 96, 115-128.

Blaxter, K. L., Kay, R. N. B., Sharman, G. A. M., Cunningham, J. M. M. \& Hamilton, W. J. 1974: Farming the red deer. Dept. Agriculture and Fisheries for Scotland. Her Majesty's Stationery Office, Edinburgh.

Brockway, J. H. \& Maloiy, G. M. O. 1976: Energy metabolism of the red deer. J. Physiol. Lond. 194, 22P-24P.

Brown, R. D., Cowan, R. L. \& Kavanaugh, J. F. 1978: Effect of pinealectomy on seasonal androgen titers, antler growth and feed intake in white-tailed deer. J. Anim. Sci. 47, 435440 .

Brown, W. B., Forbes, J. M., Goodall, E. D., Kay, R. N. B. \& Simpson, A. M. 1979: Effects of photoperiod on food intake, sexual condition and hormone concentrations in stags and rams. J. Physiol. Lond. 296, $58 \mathrm{pp.}$

Bubenik, G. A. 1983: Shift of seasonal cycle in white-tailed deer by oral administration of melatonin. J. Exp. Zool. 225, 155-156.

Bubenik, G. A. \& Bubenik, A. B. 1978: Thyroxine levels in male and female white-tailed deer (Odocoileus virginianus). Can. J. Physiol. Pharmacol. 56, 945-949.

Bubenik, G. A., Bubenik. A. B., Brown, G. M., Trenkle. A. \& Wilson, D. I. 1975: Growth hormone and cortisol levels in the annual cycle of white-tailed deer (Odocoileus virginianus). Can. J. Physiol. Pharmacol. 53, 787-792.

Clutton-Brock, T. H., Iason, G. R., Albon, S. D. \& Guinness, F. E. 1982: Effects of lactation on feeding behaviour and habitat use in wild red deer hinds. J. Zool. Lond. 198, 227-236.

Dauphiné, Jr., T. C. 1976: Biology of the Kaminuriak population of barren-ground caribou. Part 4: Growth, reproduction and energy reserves. Can. Wildl. Serv. Rpt. Ser. 38, $1-71$.

Eickhoff, W. 1957: Über das jahreszyklische Verhalten der Schilddrüsen von verschiedenen Wildarten. Frankf. Zeitschr. Path. 68, 11-26.

Eriksson, L.•O., Källquist, M.-L. \& Mossing, T. 1981: Seasonal development of circadian and short-term activity in captive reindeer, Rangifer tarandus tarandus L. Oecologia, Berlin. $48,64-70$.

Forbes, J. M., Driver, P. M., Brown, W. B., Scanes, C. G. \& Hart, I. C. 1979: The effect of daylength on the growth of lambs. 2. Blood concentrations of growth hormone, prolactin, insulin and thyroxine, and the effect of feeding. Anim. Prod. 29, 43-51.

French, C. E., McEwen, L. C., Magruder, N. D., Ingram, R. H. \& Swift, R. W. 1956: Nutrient requirements for growth and antler development in the white-tailed deer. J. Wildl. Manage. 20, 221-232.

Goss, R. J. 1969a: Photoperiodic control of antler cycles in deer. 1. Phase shift and frequency changes. J. Exp. Zool. 170, 311-324. 
Goss. R. J. 1969b: Photoperiodic control of antler cycles in deer. Il. Alterations in amplitude. J. Exp. Zool. 171, 223234.

Goss. R. J. 1976: Photoperiodic control of antler cycles in deer. III. Decreasing versus increasing daylengths. J. Exp. Zool. 197. 307-312.

Graflin. A. L. 1942: A study of the thyroid gland in specimens of Virginia deer taken at intervals throughout the year. $J$. Morphol. 70, 21-40.

Hjeljord, O.. Sundstøl. F. \& Hagenrud, H. 1982: The nutritional value of browse to moose. J. Wildl. Manage. 46. 333-343.

Hoffman. R. A. \& Robinson. P. F. 1966: Changes in some endocrine glands of white-tailed deer as affected by season. sex and age. J. Mammol. 47. 266-280

Holleman. D. F. Luick. J. R. \& White. R. G. 1979: Lichen intake estimates for reindec $r$ caribou during winter. J. Wildl. Manage. 43, 192-201.

Knorre. E. P. 1961: Itogi i perspektivy odomas̉nenija losja. Trudy Pečoro-llycskogo gos. zapov. IX, 5-113.

Lincoln. G. A. 1971: The seasonal reproductive changes in the red deer stag (Cervus elaphus). J. Zool. Lond. 163. 105-123.

Lincoln. G. A. \& Short. R. V. 1980: Seasonal breeding: Nature's contraceptive. Rec. Prog. Horm. Res, 36, 1-43.

McEwan. E. W. 1968: Growth and development of the barren-ground caribou. II. Postnatal growth rates. Can.J. Zool. 76. 1023-1029.

McEwan. E. H. 1975: The adaptive significance of the growth patterns in cervid compared with the other ungulate species. Zool. Zh. 54, 1221-1232.

McEwan. E. H. \& Whitehead. P. E. 1970: Seasonal changes in the energy and nitrogen intake in reindeer and caribou. Can. J. Zool. 48, 905-913

Milnc. J. A.. Macrae. J. C. Spence. A. M. \& Wilson. S. 1978: A comparison of the voluntary intake and digestion of a range of forages at different times of year by the stheep and the red deer. Br. J. Nutr. 40. 347-357

Mirarchi, R. E.. Howland. B. E.. Scanlon, P. F., Kirkpatrick. R. L. \& Sanford. L. M. 1978: Seasonal variation in plasma LH. FSH. prolactin. and testosterone concentrations in adult male white-tailed deer. Can. J. Zool. 56, 121-127.

Mitchell. B.. McCowan. D. \& Nicholson. 1. A. 1976: Annual cycles of body weight and condition in Scottish red deer. Cerius elaphus. J. Zool. Lond. 180. 107-127.

Moen. A. N. 1973: Wildlife Ecology. An Analytical Approach. W. H. Freeman \& Co.. San Francisco. Pp. 1-458.

Nicolls. K. E. 1971: A light microscopic study of nuclear and cyptoplasmic size of the aggregate acidophil population in the hypohysis cerebri pars distalis. of adult male mule deer, Odocoileus hemionus hemionus, relative to seasons of the photoperiod and antler cycles. Z. Zellforsch. 115. 314-326.

Nilssen. K. J. \& Ringberg. T. 1980: Seasonal changes in body weight. food intake and thyroxine in free ranging and captive Svalbard reindeer. Rangifer tarandus platyrhynchus. Pp. 329-332 in Reimers. E.. Gaare. E. \& Skjenneberg, S. (eds.): Proc. 2nd International Reindeer/Caribou Symposium. Roros. Norway 1979. Direktoratet for vilt og ferskvannsfisk. Trondheim.

Nilssen. K.. Sundsfjord. J. A. \& Blix, A. S. 1982: Energetics of the high arctic $\left(77-81^{\circ} \mathrm{NL}\right)$ Svalbard reindeer. Fed. Proc. 4). 1238

Nordan. H. C.. McTaggart Cowan. I. \& Wood. A. J. 1968: Nutritional requirements and growth of black-tailed deer. Odocoileus hemionus columbianus, in captivity. Pp. 89-96 in Crawford. M. A. (ed.): Comparative Nutrition of Wild Animals. Symp. Zool. Soc. Lond. 21 .

Oelschlaeger, A., Warren, R. J., Scanlon, P. F., Kirkpatrick, R. L. \& Gwazdauskas, F. C. 1980: Seasonal variation in serum triodothyronine (T3) and thyroxine (T4) concentrations of adult male white-tailed deer. Virginia J. Sci. 31, 101.

Pantić. V. \& Stosić. N. 1966: Investigations of the thyroid of deer and roe-bucks. Acta Anat. 63. 580-590.

Pollock. A. M. 1975: Seasonal changes in appetite and sexual condition in red deer stags maintained on a six-month photoperiod. J. Physiol. Lond. 244, 95P-96P.

Raisz. L. G. \& Krcam. B. E. 1981: Hormonal control of skeletal growth. Ann. Rev. Physiol. 43, 225-238.

Ringberg. T. 1979: The Spitzbergen reindeer - a winterdormant ungulate? Acta Physiol. Scand. 105, 268-273.

Ringberg. T.. Jacobsen. E. . Ryg, M. \& Krog, J. 1978: Seasonal changes in levels of growth hormone, somatomedin and thyroxine in free-ranging, semidomesticated reindeer (Rangifer tarandus tarandus L.). Comp. Biochem. Physiol. 60A, 123126.

Ryg. M. \& Jacobsen, E. 1981: Virkninger av ernæring på serumnivåer av thyroxin og triiodothyronin hos rein (Rangifer tarandus tarandus). Rangifer 1, 4-9.

Ryg. M. \& Jacobsen. E. 1982a: Seasonal changes in growth, feed intake, growth hormone and thyroid hormones in young male reindeer (Rangifer tarandus tarandus). Can. J. Zool. 60. 15-23.

Ryg. M. \& Jacobsen, E. 1982b: Effects of castration on growth and food intake cycles in young male reindeer (Rangifer tarandus tarandus). Can. J. Zool. 60, 942-945.

Ryg, M. \& Jacobsen, E. 1982c: Effects of thyroid hormones and prolactin on food intake and weight changes in young male reindeer (Rangifer tarandus tarandus). Can. J. Zool. $60.1562-1567$

Ryg. M. \& Langvatn. R. 1982: Seasonal changes in weight gain, growth hormone and thyroid hormones in male red deer (Cervus elaphus atlanticus). Can. J. Zool. 60, 2577-2581.

Ryg. M. 1982: Seasonal changes in weight gain, growth hormone and thyroid hormones in intact and castrated male moose (Alces alces alces). Can. J. Zool. 60, 2941-2946.

Ryg. M. 1983: Advances in the physiological studies in the reindeer/caribou in 1978-82. Acta Zool. Fenn. 175, 77-80.

Seal. U. S., Verme. L. J., Ozoga, J. J. \& Ericson, A. W. 1972: Nutritional effects on thyroid activity and blood of whitetailed deer. J. Wildl. Manage. 36. 1041-1052.

Seal. U. S. . Verme, L. J. \& Ozoga, J. J. 1978: Dietary protein and energy effects on deer fawn metabolic patterns. J. Wildl. Manage. 42, 776-790.

Segal, A. N. 1962: Sutočnye i sezonnye izmenenija gazoenergitičeskogo obmena u severnego olenja v svjazi z ekologičeskimi uslovijami suščestvovanija. Voprosy ekologii 6, 129-130.

Schulte, B. A., Seal, U. S., Plotka, E. D., Verme, L. J., Ozoga, J. J. \& Parsons, J. A. 1980: Seasonal changes in prolactin and growth hormone cells in the hypophyses of white-tailed deer (Odocoileus virginianus borealis) studied by light microscopic immunocytochemistry and radioimmunoassay. Am.J. Anat. 159, 369-378.

Schulte, B. A.. Seal, U. S., Plotka, E. D., Letellier, M. A., Verme, L. J., Ozoga, J. J. \& Parsons, J. A. 1981a: The effect of pinealectomy on seasonal changes in prolactin secretion in the white-tailed deer (Odocoileus virginianus borealis). Endocrinology 108, 173-178.

Schulte. B. A. Seal. U. S., Plotka, E. D., Verme, L. J., Ozoga, 
J. J. \& Parsons, J. A. 1981b: Characterization of seasonal changes in prolactin and growth hormone cells in the hypophyses of white-tailed deer (Odocoileus virginianus borealis) by ultrastructural and immunocytochemical techniques. $\mathrm{Am}$. J. Anat. 160, 277-284.

Silver, H., Colovos, N. F., Holter, J. B. \& Hayes, H. H. 1969: Fasting metabolism of white-tailed deer. J. Wildl. Manage. 33. 490-498.

Snyder, D. L., Cowan, R. L., Hagen, D. R. \& Schanbacher, B. D. 1983: Effect of pinealectomy on seasonal changes in antler growth and concentrations of testosterone and prolactin in white-tailed deer. Biol. Reprod. 29, 63-71.

Skjenneberg, S. 1965: Rein og reindrift. A.S. Fjell-nytt, Lesjaskog. $326 \mathrm{pp}$.

Staaland, H., Jacobsen, E. \& White, R. G. 1979: Comparison of the digestive tract in Svalbard and Norwegian reindeer. Arctic Alp. Res. 11, 457-466.

Stošić, N. \& Pantić, V. 1966: Cyclic changes in deer pituitary. Iugosl. Physiol. Pharmacol. Acta 2, 231-237.

Suttie, J. M. 1980: Influence of nutrition on growth and sexual maturation of captive red deer stags. Pp. 341-349 in Reimers, E., Gaare, E. \& Skjenneberg, S. (eds.): Proc. 2nd. Interna- tional Reindeer/Caribou Symposium, Røros, Norway 1979. Direktoratet for vilt og ferskvannsfisk, Trondheim.

Wandeler, A. \& Huber, W. 1969: Gewichtswachstum und jahreszeitliche Gewichtschwankungen bei Reh und Gemse. Rev. Suisse Zool. 76, 686-696.

Weiner, J. 1977: Energy metabolism of the roe deer. Acta Theriol. 22, 3-24.

West, N. O. \& Nordan, H. C. 1976: Hormonal regulation of reproduction and the antler cycle in the male columbian black-tailed deer (Odocoileus hemionus columbianus). Part II. The effect of metallibure and hormone treatment. Can. J. Zool. 54, 1637-1656.

Westra, R. \& Hudson, R. J. 1981: Digestive function of wapiti calves. J. Wildl. Manage. 45, 148-155.

White, R. G. 1979: Nutrient acquisition and utilization in arctic herbivores. Pp. 13-50 in Underwood, L. S., Tiezen, L. L., Callahan, A. B. \& Folk, G. E. (eds.), Comparative Mechanisms of Cold Adaptation. Academic Press, New York, London, Toronto, Sydney, San Francisco.

Yousef, M. K. \& Luick, J. R. 1971: Estimation of thyroxine secretion rate in reindeer, Rangifer tarandus: Effects of sex, age and season. Comp. Biochem. Physiol. 40A, 789-795. 
